\title{
Pilomatricoma: Experience of The Hospital for Sick Children
}

\author{
Tatiana Karine Simon Cypel MD, Vijith Vijayasekaran MBBS FRACS (plast), Gino R Somers MBBS BMedSc PhD FRCPA, \\ Ronald Melvin Zuker MD FRCSC FACS FAAP
}

TKS Cypel, V Vijayasekaran, GR Somers, RM Zuker. Pilomatricoma: Experience of The Hospital for Sick Children. Can J Plast Surg 2007;15(3):159-161.

BACKGROUND: Pilomatricoma (calcifying epithelioma of Malherbe) is a common skin neoplasm in the pediatric population that is often misdiagnosed as other skin conditions or tumours.

OBJECTIVES: The objective of the present retrospective study was to review the clinical and histopathological presentation of this neoplasm in children.

METHODS: The records of the pathology department at The Hospital for Sick Children, Toronto, Ontario, were searched for all cases of pilomatricoma between 2001 and 2006. The records of these patients were reviewed to determine sex, age, location and size of the tumour, pathological features and recurrence rate. All patients underwent surgical excision of the lesions.

RESULTS: A total of 93 lesions in 85 patients were identified. The median age was 8.7 years. Of the 85 patients diagnosed with pilomatricoma, 44 (52\%) were female. In all cases, the initial presentation was an asymptomatic, slow growing, superficial hard mass with bluish discolouration. The most common sites of occurrence were the face (48\%), neck (21\%) and upper limbs (18\%). The size of the surgical specimens collected ranged from $0.1 \mathrm{~cm}$ to $2.6 \mathrm{~cm}$. The diagnosis was confirmed by histopathological examination in all cases. Ghost cells and basaloid cells were described in most of the cases (83\%). There were no recurrences in this series.

CONCLUSIONS: This entity should be considered with other benign or malignant conditions in the clinical differential diagnosis of solitary firm skin nodules, especially those on the face, neck and upper limbs. The diagnosis can generally be made by clinical examination. The treatment of choice is surgical excision, and the recurrence rate is very low.

Key Words: Calcifying epithelioma of Malherbe; Pilomatricoma; Pilomatrixoma

\section{Le pilomatrixome : expérience au Hospital for Sick Children}

CONTEXTE : Le pilomatrixome (épithélioma calcifié de Malherbe) est un néoplasme de la peau fréquent chez les enfants et souvent confondu avec d'autres affections ou tumeurs de la peau.

BUT : La présente étude rétrospective avait pour but d'examiner les manifestations cliniques et histopathologiques de ce type de tumeur chez les enfants.

MÉTHODE : Nous avons d'abord passé en revue les dossiers rangés au service de pathologie de l'Hospital for Sick Children, à Toronto, en Ontario, à la recherche de tous les cas de pilomatrixome enregistrés entre 2001 et 2006. Nous avons ensuite examiné les dossiers extraits afin de noter l'âge et le sexe des patients ainsi que le siège, la grosseur, les caractéristiques pathologiques des tumeurs et le taux de récurrence. Toutes les lésions ont été excisées chirurgicalement.

RÉSULTATS : Au total, 93 lésions ont été relevées chez 85 patients; l'âge médian était de 8,7 ans. Chez les 85 patients en question, 44 (52\%) étaient des filles. Dans tous les cas, la tumeur s'est manifestée au départ par une masse dure, superficielle, asymptomatique, à croissance lente et de teinte bleutée. Les sièges les plus fréquents de la lésion étaient la face (48\%), le cou (21\%) et les membres supérieurs (18\%). La taille des pièces opératoires variait de 0,1 à 2,6 cm. Dans tous les cas, le diagnostic a été confirmé par un examen histopathologique et, dans presque tous les cas $(83 \%)$, on a fait état de la présence de cellules pâles et de cellules basaloïdes. Aucune récurrence n'a été observée dans la présente série. CONCLUSIONS : Il faudrait envisager ce type de tumeur au même titre que d'autres affections bénignes ou malignes dans le diagnostic différentiel de nodules fermes, isolés, de la peau, en particulier de ceux qui touchent la face, le cou ou les membres supérieurs. Le diagnostic est généralement posé à partir de l'examen clinique, le traitement de première intention est l'excision chirurgicale et le taux de récurrence est très faible.
$\mathrm{P}_{\mathrm{i}}^{\mathrm{i}}$ ilomatricoma, formerly known as pilomatrixoma or calcifying epithelioma of Malherbe, is a benign skin neoplasm that arises from the hair follicle matrix cell $(1,2)$. Pilomatricoma was first described in 1880 by Malherbe and Chenatais (3), who thought the lesion originated from sebaceous glands. In 1961, Forbis and Helwing (4) described the same lesion and attributed its origin to the hair matrix; therefore, the term pilomatrixoma was proposed to correctly describe its origin, thereby avoiding the word epithelioma, which carries a connotation of malignancy. The majority of authors most commonly use the term pilomatricoma or trichomatricoma to describe the lesion because it is etymologically more accurate (5).
Clinically, pilomatricoma usually presents as a superficial hard mass with bluish discolouration, and may involve ulceration of the overlying skin (6) (Figure 1). The firm component is smooth but often irregular, and can be easily moved with the overlying skin. It is not fixed to the deeper tissues. Pilomatricomas commonly occur in children, most frequently in the head and neck region (Figure 2). They are the second most commonly excised superficial mass in children after epidermoid cysts, excluding lymph nodes (1). However, pilomatricomas are frequently misdiagnosed and/or missed in the differential diagnosis. Surgical removal is curative. Recurrence after complete local excision is rare. Malignancy degeneration has been rarely reported (7). 


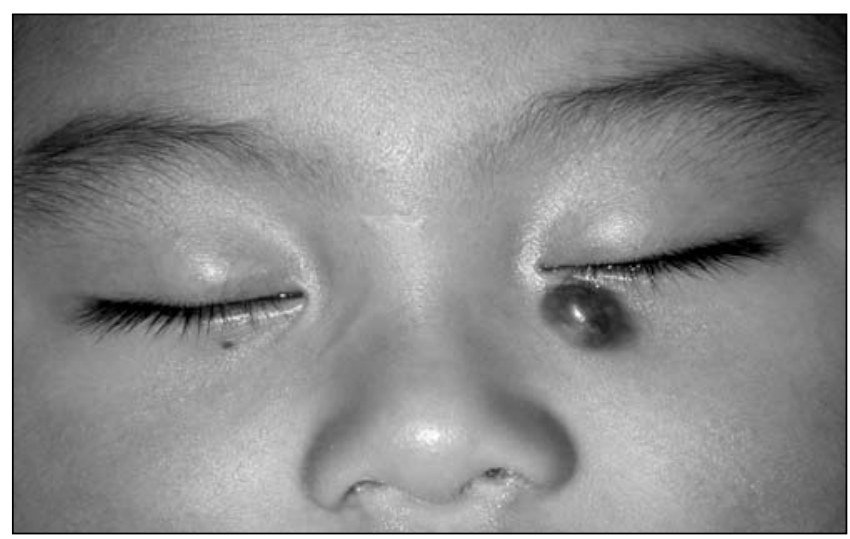

Figure 1) Preoperative appearance of a pilomatricoma of the face

\section{METHODS}

Pathology department records from The Hospital for Sick Children, Toronto, Ontario, were searched for all cases of pilomatricoma between 2001 and 2006. The records of these patients were reviewed to determine sex, age, location, size of the tumour, pathological features and recurrence rate. All patients underwent surgical excision of the lesions.

\section{RESULTS}

A total of 93 lesions in 85 patients were identified. The median age was 8.7 years, ranging from 11 months to 17 years. Of the 85 patients diagnosed with pilomatricoma, 44 (52\%) were female and $41(48 \%)$ were male. In all cases, the initial presentation was an asymptomatic, slow growing, superficial hard mass with bluish discolouration.

The most common sites of occurrence were the face (48\%), especially in the periorbital and cheek regions, neck $(21 \%)$, upper limbs (18\%), trunk (9\%) and lower limb (4\%). The left side was affected in $54 \%$ of cases. Bilateral lesions were found in only $1 \%$ of the cases. The size of the surgical specimens collected ranged from $0.1 \mathrm{~cm}$ to $2.6 \mathrm{~cm}$, with average of $1.7 \mathrm{~cm}$. Multiple lesions were observed in only three patients, while 82 patients presented with a solitary lesion. The diagnosis was confirmed by histopathological examination in all cases. Ghost cells and basaloid cells were described in most of the cases $(83 \%)$ and calcification was reported in $17 \%$ of the lesions. There were no recurrences in this series.

\section{DISCUSSION}

Pilomatricoma was initially thought to arise from sebaceous glands and was called calcifying epithelioma of Malherbe by Malherbe and Chenantais in 1880 (3). In 1922, Dubreuilh and Cazenave (8) described the unique histopathological characteristics of this neoplasm, including islands of epithelial cells and shadow cells. In 1961, after histochemical and electron microscopic analysis of 228 such tumours, Forbis and Helwing (4) found the cell of origin to be the outer root sheath cell of the hair follicle and proposed the name, pilomatrixoma, now called pilomatricoma.

In 1973, Moehlenbeck (9) reviewed 140,000 skin tumours and noted that pilomatricoma represented $0.12 \%$ of these cases. Although pilomatricoma can develop in patients of any age, it occurs most often in children and young adults (2). Among the young, $40 \%$ of cases occur before the age of 10 years and $60 \%$ of cases occur before the age of 20 years $(2,9,10)$. However, a

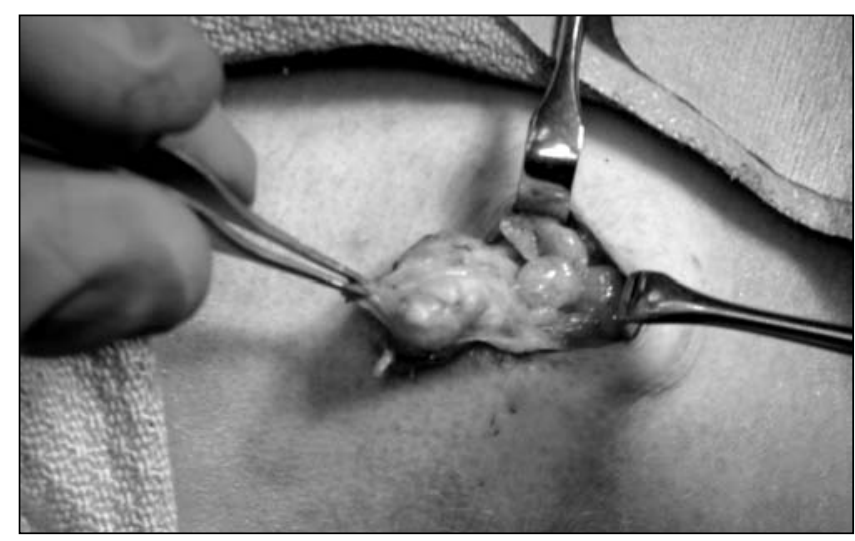

Figure 2) Intraoperative appearance of a pilomatricoma in the neck

second, smaller peak in onset has been reported in the elderly (10). The female to male ratio is $2: 1(11)$.

Pilomatricomas most commonly occur in the the head and neck, with between $40 \%$ and $77 \%$ diagnosed in this region (2). The second most common site is the upper extremities, followed by the trunk and lower extremities $(2,6,9)$. In the head and neck region, the most frequent locations are the neck and the frontal, temporal, periorbital and preauricular areas $(6,7,12,13)$.

The diagnosis of pilomatricoma can be made clinically if the characteristics of the tumour are known; pilomatricoma lesions slide freely over the underlying tissue. Graham and Merwin (14) described the 'tent sign', elicited by stretching the skin over the pilomatricoma tumour to feel the irregular surface of mass. There is no associated lymphadenopathy. A blue discolouration may be seen. Problems in the clinical differential diagnosis may arise because pilomatricoma may occur at any age and it may have uncommon clinical features, such as multicentricity, large size or deep location (15). Although the superficial location of the majority of these tumours make routine evaluation by means of imaging studies unnecessary, in patients with an abnormal aspect of some lesion, ultrasound (occasionally computed tomography) (16) and fine-needle aspiration cytology (15) may be helpful. Pilomatricomas in the parotid region have been mistaken for parotid neoplasms, because they can involve salivary parotid gland tissue (17). Ultrasonographic findings can demonstrate the superficial position, the continuity of the lesion with deeper structures and the degree of calcification. Ultrasonography is a low-cost, noninvasive tool and is more appropriate for younger children because there is no need for sedation or anesthesia (16). Although computed tomography is less often used for the diagnosis of pilomatricoma, it can demonstrate a well-marginated, subcutaneous, soft-tissue mass adherent to the skin, with or without visible calcification (18). Fine-needle aspiration may reveal the presence of ghost cells, basaloid cells and calcium deposition in the mass, findings that are diagnostic of pilomatricoma. However, without the presence of ghost cells in the aspirate, the diagnosis may be misleading (19).

Histopathological examination of pilomatricoma shows sharply demarcated dermal nodules surrounded by a capsule of compressed fibrous tissue located in the lower dermis and extending into the subcutaneous fat. The cells in the islands are arranged in a circular configuration, with nucleated basaloid cells on the periphery and enucleated shadow cells in the centre. The basaloid cells exhibit both deeply staining nuclei 
with scant cytoplasm, and lack distinct cell borders. The shadow cells, also termed ghost cells, which evolve from basaloid cells, represent dead cells that retain their cellular shape and show a central unstained area that corresponds to the lost nucleus. The transitional cells, which are localized between basaloid cells and shadow cells, were thought to represent apoptotic cells that were finally proceeding to shadow cells. Calcification is mostly seen in the ghost cell regions, with the incidence ranging from $69 \%$ to $85 \%$. Foreign body giant cell reaction, which represents a granulomatous response to the shadow cells, can also be identified in regions where keratinized debris is abundant $(6,11,20)$.

Malignant transformation is rare. Malignant pilomatricomas tend to occur in middle-aged or elderly patients. The histological features of pilomatrix carcinoma include proliferating basaloid cells with atypical mitoses and nuclear pleomorphism, invasion of blood vessels and infiltration into underlying structures $(6,10)$. Rare cases of pilomatrix carcinoma with distant metastasis have been reported.

Recent studies have shown that pilomatricomas are frequently associated with beta-catenin mutations. Beta-catenin, a $92 \mathrm{kDa}$ protein, is a structural component of adherence junctions in almost all normal tissues and plays a key role in regulating normal cell growth and function. It is also involved in signal transduction in the Wnt signalling pathway and has been identified as an oncogene in colon cancer and melanoma. It gene map locus is 3p22-p21.3 (11). Hassanein et al (21)

\section{REFERENCES}

1. Knight PJ, Reiner BC. Superficial lumps in children: What, when and why? Pediatrics 1983;72:147.

2. Yencha MV. Head and neck pilomatricoma in the pediatric age group: A retrospective study and literature review. Int J Pediatr Otorhinolaryngol 2001;57:123.

3. Malherbe A, Chenantais J. Note sur l'epitheliome calcifie des glandes sebaces. Prog Med 1880:826-837.

4. Forbis R, Helwing EB. Pilomatrixoma (calcyfing epithelioma). Arch Dermatol 1961;83:606-8.

5. Arnold HL. Pilomatricoma. Arch Dermatol 1977;13:1303.

6. Duflo S, Nicollas R, Roman S, Magalon G, Triglia JM. Pilomatrixoma of head and neck in children: A study of 38 cases and a review of the literature. Arch Otolaryngol Head Neck 1998; $124: 1239$

7. Danielson-Cohen A, Lin SJ, Hughes A, An YH, Maddalozzo J. Head and neck pilomatrixoma in children. Arch Otolaryngol Head Neck 2001;127:1481-3.

8. Dubreuilh W, Cazenave E. De l'epithelioma calcifie: etude histologique. Ann Dermatol Syphilol 1922;3:257-68.

9. Moehlenbeck F. Pilomatrixoma (calcifying epithelioma): A statistical study. Arch Dermatol 1973;108:532-4.

10. Julian CG, Bowers PW. A clinical reviw of 209 pilomatricomas. J Am Acad Dermatol 1998;39:191-5.

11. Cigliano B, Baltogiannis N, De Marco M, et al. Pilomatricoma in childhood: A retrospective study from three European paediatric centres. Eur J Pediatr 2005;164:673-7.

12. Agarwall RP, Handler SD, Matthews MR, Carpentieri D. Pilomatrixoma of the head and neck in children. Otoryngol Head Neck Surg 2001;125:510-5.

13. Thomas RW, Perkins JA, Ruegemer JL, Munaretto JA. Surgical excision of pilomatrixoma of head and neck. Ear Nose Throat J $1999 ; 78: 541-8$

14. Graham JL, Merwin CF. The tent sign of pilomatrixoma. Cutis 1978;22:577-80.

15. Lemos MM, Kindblom LG, Meis-Kindblom JM, Ryd W, Willén H. Fine-needle aspiration features of pilomatrixoma. Cancer 2001;93:252-6.

16. Hughes J, Lam A, Rogers M. Use of ultrasonography in the diagnosis have confirmed that beta-catenin mutations occur not only in pilomatricoma but also in pilomatrix carcinomas by immunohistochemical staining for beta-catenin in normal scalp follicles, pilomatrixomas and pilomatrix carcinoma. Other authors $(21,22)$ conclude that beta-catenin mutation in matrix cells of hair follicles stabilizes beta-catenin protein, and thus translocates into the nucleus, where it activates gene transcription along with lymphoid enhancer factor-1, thereby producing pilomatricoma. These mutations occur without an underlying defect in DNA mismatch repair $(21,22)$.

Occasionally, there may be a history of previous trauma to the tumour site, but this association in unusual (7). Finally, pilomatricoma can be associated with other diseases such as myotonic dystrophy (Steinert disease), frontoparietal baldness, sarcoidosis, Turner syndrome, Raynaud phenomenon or Gardner syndrome (23-27). The differential diagnosis for pilomatricoma is varied. Pilomatricomas may be mistaken for epidermoid or dermoid cysts, calcified lymph nodes, calcified hematomas, hemangiomas and parotid gland tumours $(28,29)$.

Because spontaneous regression of pilomatricoma has never been observed and malignant degeneration is rare, surgical excision with clear margins (including the overlying skin if the tumour is adherent to the skin) is the treatment of choice, thereby avoiding recurrence due to incomplete resection. The incidence of recurrences after surgery has been reported to be between $0 \%$ and $6 \%(2,6,7,20,26,29)$.

of childhood pilomatrixoma. Pediatr Dermatol 1999;16:341-4.

17. Brandner MD, Bunkis J. Pilomatrixoma presenting as parotid mass. Plastic Reconstr Surg 1986;78:518.

18. Som PM, Shugar JM, Silvers AR. CT of pilomatrixoma in the cheek. AJNR Am J Neuroradiol 1998;19:1219.

19. Domanski HA, Domanski AM. Cytology of pilomatrixoma (calcifying epithelioma of Malherbe) in fine needle aspirates. Acta Cytol 1997;41:771-7.

20. Lan MY, Lan MC, Ho CY, Li WY, Lin CZ. Pilomatrixoma of the head and neck: A retrospective review of 179 cases. Arch Otolaryngol Head Neck Surg 2003;129:1327-30.

21. Hassanein AM, Glanz SM. Beta-catenin expression in benign and malignant pilomatrix neoplasms. Br J Dermatol 2004;150:511-6.

22. Moreno-Bueno G, Gamallo C, Perez-Gallego L, Contreras F, Palacios J. Beta-catenin expression in pilomatrixomas. Relationship with beta-catenin gene mutations and comparison with beta-catenin expression in normal hair follicles. $\mathrm{Br} \mathrm{J}$ Dermatol 2001;145:576-81.

23. Barberio E, Nino M, Dente V, Delfino M. Multiple pilomatrixomas and Steinert's disease. Eur J Dermatol 2002;12:293-4

24. Cooper PH, Fechner RE. Pilomatricoma-like changes in the epidermal cysts of Gardner's syndrome. J Am Acad Dermatol 1983;8:639-44.

25. Delfino M, Monfrecola G, Ayala F, Suppa F, Piccirillo A. Multiple familial pilomatricomas: A cutaneous marker for myotonic dystrophy. Dermatologica 1985;170:128-32.

26. Jacobsen AS, Bowen J, Bruce J. The calcifying epithelioma of Malherbe in children: A 15-year experience. Pediatric Surg Int 1995;10:44-5.

27. McCilloch TA, Singh S, Cotton DW. Pilomatrix carcinoma and multiple pilomatrixomas. Br J Dermatol 1996;134:368-71.

28. Wells NJ, Blair GK, Magee JF, Whiteman DM. Pilomatrixoma: A common, benign childhood skin tumour. Can J Surg 1994:37:483

29. Pirouzmanesh A, Reinisch JF, Gonzalez-Gomez I, Smith EM, Meara JG. Pilomatrixoma: A review of 346 cases. Plast Reconst Surg 2003;112:1784-9. 